\title{
Threatened Fishes of the World: Silvinichthys bortayro (Fernandez and de Pinna, 2005) (Trichomycteridae)
}

\author{
Luis Fernandez
}

Received: 15 April 2009 / Accepted: 20 October 2009 /Published online: 31 October 2009

(C) Springer Science + Business Media B.V. 2009

Common name: Yuska (Argentina). Conservation status: Threatened (Fernandez 2005). Identification: Silvinichthys bortayro (Ostariophysii: Siluriformes) is an endemic and endangered species from northwestern Argentina, South America. Characteristic of Trichomycteridae is the presence of a patch of odontodes on the interopercle. The species is very similar to Silvinichthys mendozensis, except for the lack of the pelvic fin and girdle, pale pigmentation, and reduction of the eyes (Fernandez and de Pinna 2005). Maximum length: $30 \mathrm{~mm}$ SL. P i+5, D ii + 7, A ii-iv+6, C 5-6/6-7. Illustration by N.P. Carvajal. Distribution: Endemic to the Arenales aquifer, above $1250 \mathrm{~m}$ above sea level, Salta Province (25 50’S/65 30’W). Abundance: Scarce everywhere. Habitat and ecology: This small catfish is an invertivore, living in groundwater. It lives in artificial wells and clean undisturbed water. It is carnivorous generalist, preying mainly on insects and crustaceans. Reproduction: November through December. Threats:

L. Fernandez $(\bowtie)$

CONICET, Instituto Fundacion Miguel Lillo,

Miguel Lillo 251,

4000 Tucumán, Argentina

e-mail: luis1813@yahoo.com

L. Fernandez

IBIGEO, Instituto Biología Geociencias,

Salta, Argentina

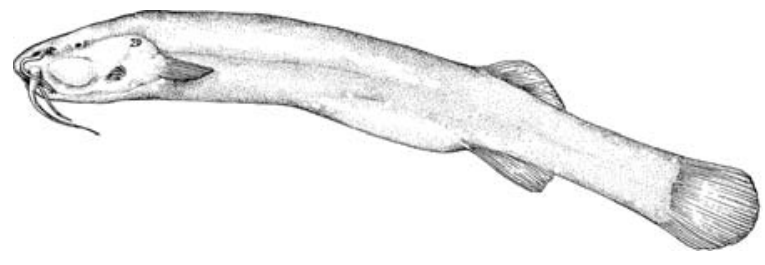

Main threats are its restricted distribution and aquifer alterations. This endemic catfish is adversely affected by human population growth, mineral extraction, and associated erosion (Fernandez 2005). The phreatic catfish is sensitive to water pollution and habitat modification. Conservation action: Aquifer protection. Conservation recommendation: Avoid overexploitation of phreatic water. Subterranean water is heavily exploited in the area of occurrence of the species. Conservation and management policies are necessary at the level of local governments.

\section{References}

Fernandez L (2005) Risk of extinction of a rare catfish of Andean groundwater and its priority for conservation. AMBIO 34(3):269-270

Fernandez L, de Pinna MCC (2005) A phreatic catfish of the genus Silvinichthys from southern South America (Teleostei, Siluriformes, Trichomycteridae). Copeia 2005 (1):100-108 